\title{
Hydrologic control in llanos de Moxos, Amazonian lowlands of Bolivia
}

\section{Opinion}

The Amazonian lowlands of Bolivia are localized between Andes and Brazilian shield, and delimited by the Fitzcarrald $\operatorname{arch}^{\text {in north }}{ }^{1}$ and the Michicolaarch in south. ${ }^{2}$ The Fitzcarrald arch uplift occurred since Pliocene ( $4 \mathrm{Ma}$ ) by the subduction of oceanic ridge below continental plate. This arch form the division of upper Madeira River from the northern rivers of Amazon. ${ }^{1}$ The Michicolaarch was formed since Oligocene (30 Ma) by the eastward propagation of Andes. Actually this arch is covered by sediments in lowlands, ${ }^{2}$ and the division between the upper Madeira-Amazon River and the Paraguay-La Plata River in this part is not prominent, experiencing the frequent changes of river courses in megafans. ${ }^{3}$

The recent revision of phylogeny, biogeography, geology and paleontology support the ancient origin of modern genus of fishes before the division of actual hydrologic basin in South America, and suggest the divergence of phenotypes during Palaeogene and the role of ecologic specialization of linages and environmental configuration for vicariance and geo-dispersal during Neogene. ${ }^{4}$ In other words, the effect of division of upper Madeira River may be observed in the difference of diversity in the species level caused by allopatric speciation. Furthermore, the effect of connection to the northern rivers of Amazon through river course might have been different between the groups of migratory species adapted to seasonal environments and sedentary species adapted to stable environments. ${ }^{5,6}$ The division between the upper Madeira River and the Paraguay River was semipermeable because of the frequent changes of river courses in mega fans and head river capture events in Sub-Andes and Brazilian shield, and the effects of these connections might be different between the groups of species adapted to lowlands and uplands ${ }^{4}$ etc.

During last decades, the exploration of ichthyologist has doubled the list of fishes in Bolivian Amazon, indicating the high level of species endemism ${ }^{7}$ however, understanding the origin and maintenance of diversity and the influence of human activity to diversity is challenge. In llanos de Moxos or the floodplain of department of Beni, numerous authors have postulated that the pre-Columbian civilization practiced the fishery by hydrologic control. Exist the archaeological sites across department, presenting the trace of civil works like weirs, elevated land areas, ponds, etc. ${ }^{8,9}$ and there mains of fishes recovered in Loma Salvatierra were the groups of species observed in the artificial ponds near the town of Trinidad, the capital departmental of Beni. ${ }^{10}$ These species colonize to ephemeras water bodies with high rate of population increase, production of dormant eggs, capacity of air breathing, etc. The processes are deterministic in the ponds connected to the floodplain during low water levels, in that seasonal breeding species with large body size and air breathing ability colonize from nearby sites, excluding small body species. The dynamics across years show the segregation of community average value for batch fecundity associated with fish density, and may be dependent of magnitude and duration of flood events. While the processes are neutral in the isolated ponds and newly flooded ponds, in that fishes are recruited in situ and dispersals are limited. The deterministic processes and the association between life history traits of species and environmental configuration
Volume 7 Issue 5 - 2018

\author{
Takayuki Yunoki \\ Centro de Investigación de Recursos Acuáticos, Universidad \\ Autónoma del Beni, Bolivia
}

\begin{abstract}
Correspondence: Takayuki Yunoki, Centro de Investigación de Recursos Acuáticos, Universidad Autónoma del Beni, José Ballivián (CIRA-UAB), Trinidad, Beni, Bolivia,
\end{abstract}

Email takayukiyunoki@yahoo.com

Received: September 13, 2018 | Published: September 26, 2018

are achieved by efficient dispersal, indicating that the species adapted to a specific type of habitat exist subsequently colonized an area after it was altered via human activities. ${ }^{11}$

Llanos de Moxos, especially Mamoré River floodplain is known for their productivity and diversity, ${ }^{12}$ however, commercial fishery is selective for large body species, establishing in the low level of exploitation. ${ }^{13}$ Furthermore, the extreme drought and flood events are causing significant economic impacts and a large number of fatalities. ${ }^{14}$ The construction of loads, elevated land areas and ponds is a common practice in civil works and ranching, and our results indicate the possibility to control the fish community organization of these artificial water bodies, managing the connectivity and local environmental conditions. The harvesting and commercialization via hydrologic control mechanisms may be advantageous for remote towns located in the tropics such as Trinidad, because of the high fish density and the ability to breathe air among fish. ${ }^{13,14}$

\section{Acknowledgements}

None.

\section{Conflict of interest}

Author declares that there is no conflict of interest.

\section{References}

1. Espurt N, Baby P, Brusset S, et al. How does the Nazca Ridge subduction influence the modern Amazonian foreland basin? The Geological Society of America. 2007;35(6):515-518.

2. Lundberg JG, Marshall LG, Guerrero BH. The stage of Neotropical fish diversification: A historiy of tropical South American rivers. In: Malabarba LR, Reis RE, editors. Phylogeny and Clasification of Neotropical fishes; 1998. p.13-48.

3. Wilkinson JM, Lundberg JG, Marshall LG. River behavior on megafans and potential influences on diversification and distribution of aquatic organisms. Journal of South American Earth Sciences. 2006;21(1):151172

4. Albert JS and Reis RE. Historical biogeography of neotropical freshwater fishes, University of California Press, Berkeley, CA. 2011. 
5. Yunoki T, Torres LV. Fish meta community dynamics in the patchy heterogeneous habitats of varzea lakes, turbid river channels and transparent clear and black water bodies in the Amazonian Lowlands of Bolivia. Environmental Biology of Fishes. 2016;99(4):391-408.

6. Yunoki T, Torres LV, Pouilly M. Comunidades ictícolas en diferentes tipos de aguas, Amazonía boliviana. Dissertation, I Congreso boliviano de ictiología. 2017.

7. Carvajal-Vallejos FM, Bigorne R, Zeballos Fernández AJ, et al. FishAMAZBOL: a database on freshwater fishes of the Bolivian Amazon. Hydrobiologia. 2014;732:19-27

8. Lee K. Apuntes sobre las obras hidrauclicas prehispánicas de las llanuras de Moxos. In Paititi, Año 11. Casa de la Cultura de Beni y Pando, Trinidad; 1997;24-26.

9. Blatrix R, Roux B, Béarez P, Prestes-Carneiro G, et al. The unique functioning of a pre- Columbian Amazonian floodplain fishery. Scientific Reports. 2018;8(5998):1-16.
10. Prestes-Carneiro G, Béarez P. Swamp-eel (Synbranchus spp.) fishing in Amazonia from pre-Columbian to present times. Journal of Ethnobiology. 2017;37(3): 380-397.

11. Yunoki T, Torres LV, Cholima RB. A metacommunity ecological approach to understanding the community organization of fish in artificial ponds of the Mamoré River floodplain in the Amazonian Lowlands of Bolivia. Environmental Biology of Fishes. 2018;101:1329-1341.

12. Lauzanne L, LoubensG, Le Gennec B. Pesca y biología pesquera en el Mamoré Medio (Región de Trinidad, Bolivia). Interciencia. 1990;15(6):452-460.

13. Schneider H. Diagnóstico ambiental de las actividades socioeconómicas más importantes del departamento del Beni. Proyecto BID ATR 929/SE - BO. 2002.

14. Ovando A, Tomasella J, Rodriguez DA, et al. Extreme flood events in the Bolivian Amazon wetlands. Journal of Hydrology: Regional Studies. 2016;5:293-308. 